特集 $*$ 水中コンクリートの現状 $/ 3.14$

\title{
ホテルコスモ／みどり会墨田寮 における事例
}

阿部照男 ${ }^{* 1}$-山田卓 司 ${ }^{* 2}$

\section{1.まえがき}

連続地中壁（以下, 地中壁と略記）を建築物の地下構 造体として利用することは，すでに一般的な手法となっ ている。最近の事例では, 鉄道やビルに近接して施工す る例や，狭险な敷地での施工など困難な現場条件に適用 する例, 若令地盤, 大転石層, 玉石層, 逸泥地盤, 岩盤 など複雑な地質条件に適用する例, 壁ぐいの形状に適用 する例など, 高度な品質管理を要求される, 地中壁の多 目的な使われ方が注目されている。

都市部においては, 地価の高謄, 過密化, 車の増加が いちだんと進み, 駐車スペースの確保が重要な問題とな り, 地下の空間利用に目が向けられている。さらに, 支 持ぐいの経済設計や合理性の面から, 壁式ぐい（長方形 断面のくい) を应底する工法や，昨今の労務事情から工 事の省力化, 効率化が求められており, これらを意図す る工法なども試みられている。

昭和 48 年に(財)日本建築センターの評定を取得して以

\section{2. 地下立体駐車場の事例}

建物の地下 1 階平面を 図一1 に, 断面を 図一2 に示 于。

市街地のホテルビルの地下に大型車 30 台, 中型車 30 台の駐車スペースを設けたもので，地中壁を建物の支持 ぐいと立体駐車場部の外壁に利用している。地中壁は, 既存拡底深礎の軸部を避けた平面配置とし, 地中壁を掘 削するときに, 無筋部分の拡底部を削り落とす計画とし ている。

\section{1 工事 概 要}

工事名称：ホテルコスモ横浜新築工事

所 在 地 : 横浜市西区北幸 2-9-1

設 計 者: (株久米建築事務所

施 工 者 : 㫼大林組

全体概要 : SRC 造

地下 2 階, 地上 11 階, 塔屋 1 階 延床面積 $4746 \mathrm{~m}^{2}$

来, さまざまな用途に地中壁工法 (OWS-Soletanche 工法) が利用 されている。この地中壁を地下構 造体 (くい・地下外壁) として用 いるものを, WF (Wall Foundation) と呼んでいる。

ここでは，WF の事例として， (1)ホテルコスモ横浜における地下 立体駐車場と, (2)みどり会墨田単 身寮における壁式桩底ぐいの概要 を紹介する。

*1 あぺ・てるお/儌大林組東京本社 特殊工法部工事課 課長

*2 やまだ・たくじ／同上＼cjkstart同課 課長代理

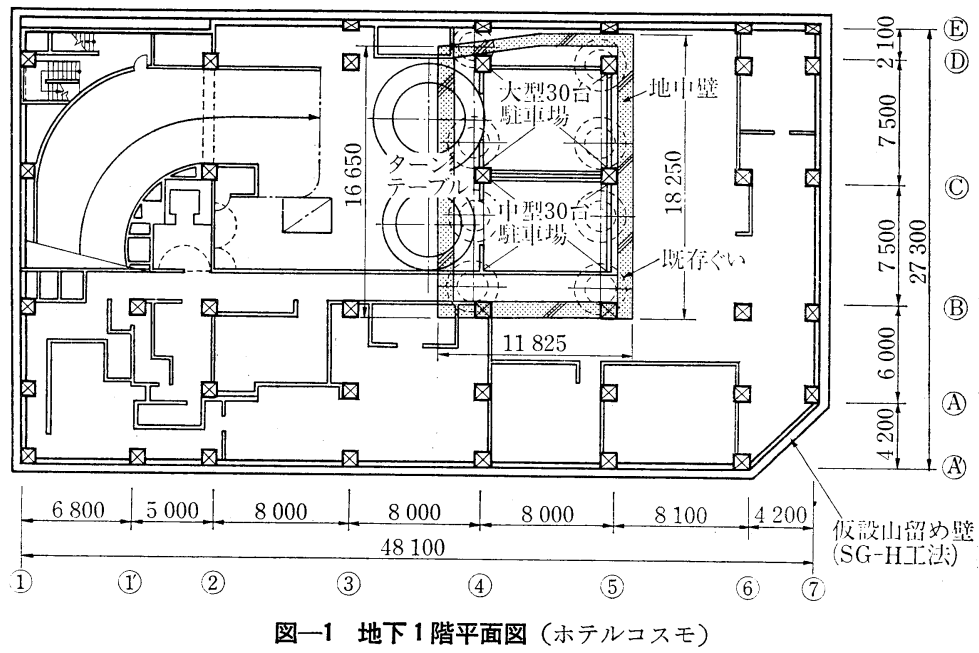


立体駐車場収容台数 : 60 台 地中壁概要

用 途: 支持ぐい, 耐震壁, 土水水圧負担壁 壁 厚 : $100 \mathrm{~cm}$

掘削深さ: GL. $-44 \mathrm{~m}$

壁 長: $55 \mathrm{~m}$

施工面積 : $2137 \mathrm{~m}^{2}$

鉄筋量: $206 \mathrm{t}$

コンクリート量 : $1870 \mathrm{~m}^{3}$

工 期：48日

2.2 掘削工事
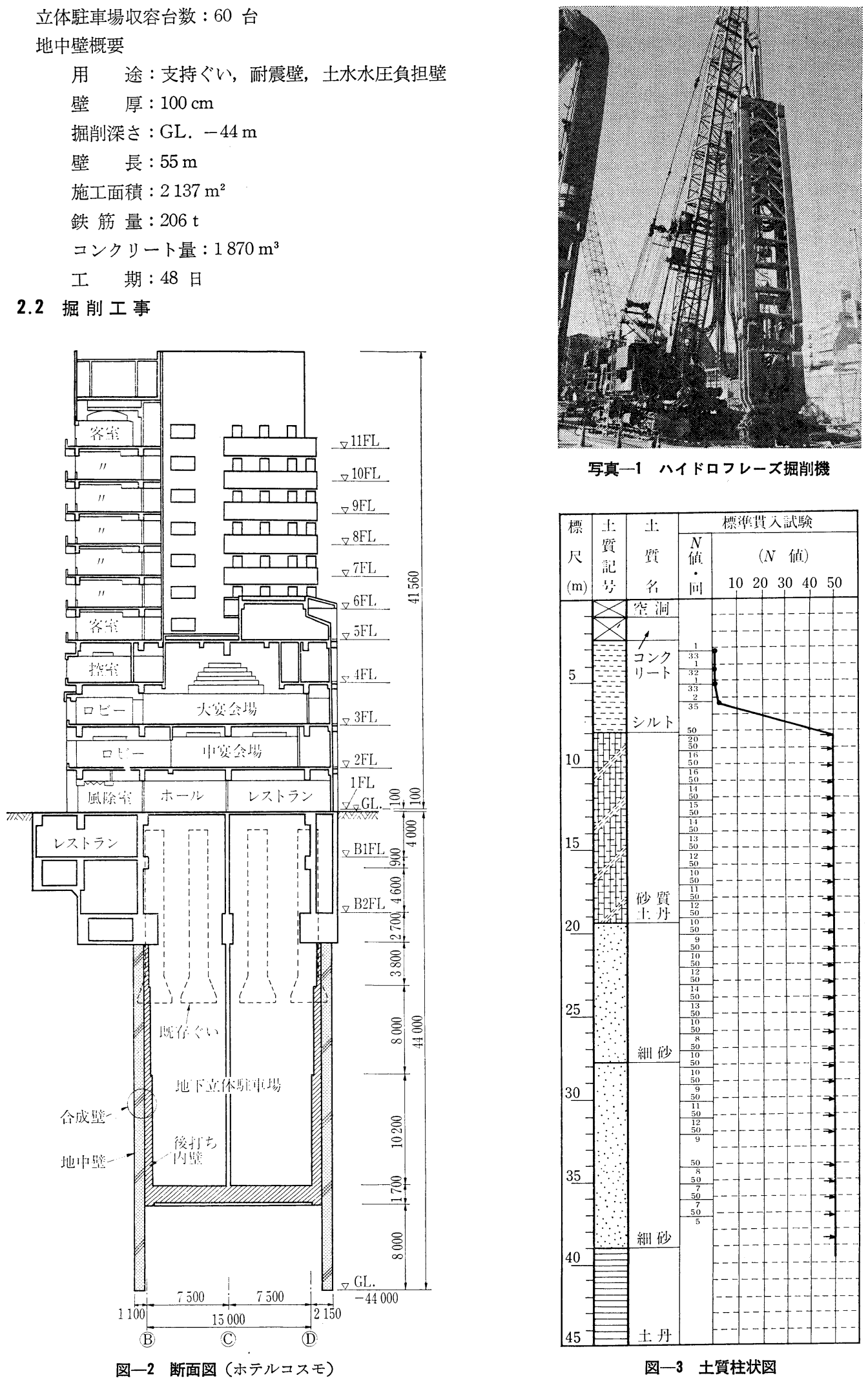

写真一1 ハイドロフレーズ掘削機

\begin{tabular}{|c|c|c|c|c|}
\hline \multirow{2}{*}{\multicolumn{2}{|c|}{\begin{tabular}{c|c} 
漂 & 土 \\
尺 & 質 \\
湤
\end{tabular}}} & \multirow[t]{2}{*}{1 : } & \multicolumn{2}{|r|}{ 槽淮:鿓入湖験 } \\
\hline & & & $N$ & \\
\hline & 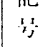 & 多 & |iil & $\begin{array}{llll}10 & 20 & 30 & 40\end{array}$ \\
\hline
\end{tabular}

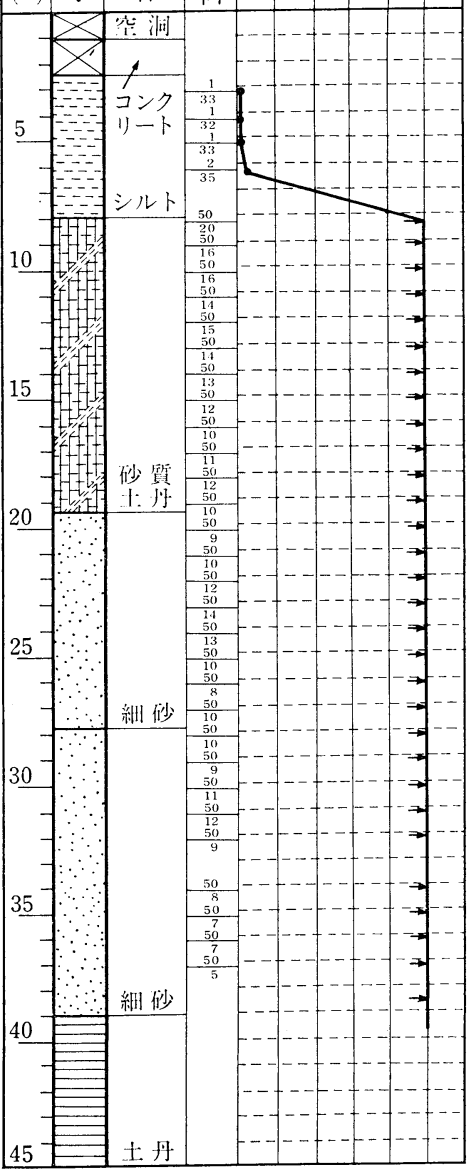

図一，土質柱状図 
掘削工事は，既存ビルの地上躯体を解体後，地下躯体 (GL. $-6.5 \mathrm{~m}$ ) の地中壁構築部分だけを撤去し, 構台上 から作業を行った。既存ぐいの深礎が GL. $-17.0 \mathrm{~m}$ まで残っているが，工期と経済性の面から深礎を撤去せ ず，ハイドロフレーズ掘削機 (写真一1) のカッタードラ ムにより深礎の拡底部を切削する方法で施工した。

大樑度掘削用のハイドロフレーズ掘削機 4000 型を使 用することで，GL， $-44 \mathrm{~m}$ までの硬質な地盤（図一3） を，能率よく高い精度で掘削することができた。

土砂分離, スライム処理については, 大型の土砂分離 装置, サイクロン, スクリューデカンタを設置し, 安定 液を循環させてクリーニングを行うとともに，入念なス ライム処理を行った。

\section{3 コンクリート工事}

コンクリートは, 普通ポルトランドセメントと普通骨 材による生コンクリートを使用した。設計基準強度 240 $\mathrm{kgf} / \mathrm{cm}^{2}$, スランプ $20 \mathrm{~cm}$, 粗骨材の最大寸法 $25 \mathrm{~mm}$, 単位セメント量 $350 \mathrm{~kg}$ 以上, 水セメント比 $55 \%$ 以下 とした。その調合を表一1に示す。調合は，トレミー管 による打込み方法をとっていることから，水中コンクリ 一トとして適切なワーカビリチーが得られるようにスラ ンプ值やセメント量などを定め, 流動性やフローが良好 で分離しにくい，粘りのあるコンクリートとなることを 重視して定めた。気温による強度の補正は，地中の温度 がほぼ一定であることと，コンクリート自身の発熱拉よ び余盛り $(1.0 \mathrm{~m})$ があることを考慮し，行っていない。

水中コンクリートでは, 安定液と完全に置換するため に粘性を高くし，材料分離を少なくする必要があること や，安定液が打込みコンクリートに混入して圧縮强度の 低下をまねくことなどを考慮して，スランプ值や単位セ メント量の限度を設定しているが，粘性，比重，砂分な ど安定液の管理およびトレミー管の根入れ長さの管理を 十分行うことで, その圧縮強度の品質は, さらに高めら れると考える。標準養生による材令 28 日の圧縮強度は $286 \sim 323 \mathrm{kgf} / \mathrm{cm}^{2}$ (平均で $304 \mathrm{kgf} / \mathrm{cm}^{2}$ ) であったが, 実 物の地中壁体は，圧密されることや地中養生されるこ と, さらに壁面の状態から推測して, 標淮養生以上の圧 縮強度の発現が予想される。

コンクリートの打設については, 鉄筋量が $115 \mathrm{~kg} / \mathrm{m}^{2}$ と多いため, スライムの巻込みを防止し, 密実なコンク リートとなるように，生コン運搬車 2 台打込み終了ごと に，検尺テープを用いてコンクリートの打上り高さを計

\section{表一1 コンクリートの調合}

\begin{tabular}{|c|c|c|c|c|c|c|c|c|}
\hline \multirow{2}{*}{$\begin{array}{l}\text { 設計基隻 } \\
\text { 强 } \\
\left(\mathrm{kg} / \mathrm{cm}^{2}\right)\end{array}$} & \multirow[b]{2}{*}{$(\mathrm{cm})$} & \multirow{2}{*}{$\begin{array}{l}\text { 水セメ } \\
W / C \\
(\%) \\
(\%)\end{array}$} & \multirow{2}{*}{$\begin{array}{c}\text { 細骨材率 } \\
s / a \\
(\%)\end{array}$} & \multicolumn{3}{|c|}{ 単 位 量 } & \multicolumn{2}{|c|}{$\left(\mathrm{kg} / \mathrm{m}^{3}\right)$} \\
\hline & & & & $C$ & $W$ & $S$ & $G$ & 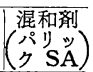 \\
\hline 240 & 20 & 55.0 & 46.1 & 358 & 180 & 802 & 972 & 3.280 \\
\hline
\end{tabular}

測し, 打設速度とトレミー管の根入れ長さの確認と調整 を行った。トレミー管は, ジョイント部からの漏水を防 ぐため，大深度用ねじ式のものを用い，プランジャー方 式によりコンクリートを打設した。コンクリートの打設 総量は $1870 \mathrm{~m}^{3}$ であったが，掘削精度が高く，その割 増率は $3.3 \%$ と小さな值であった。

\section{4 地中壁鉛直ジョイント工事}

地中壁相互の鉛直ジョイント部は, ハイドロフレーズ 掘削機のカッタードラムを用いて, 先行地中壁の端部コ ンクリートを 75 100 mm 程度の厚みでカッティングす る方法で施工した。この方法は, カッティング面が粗面

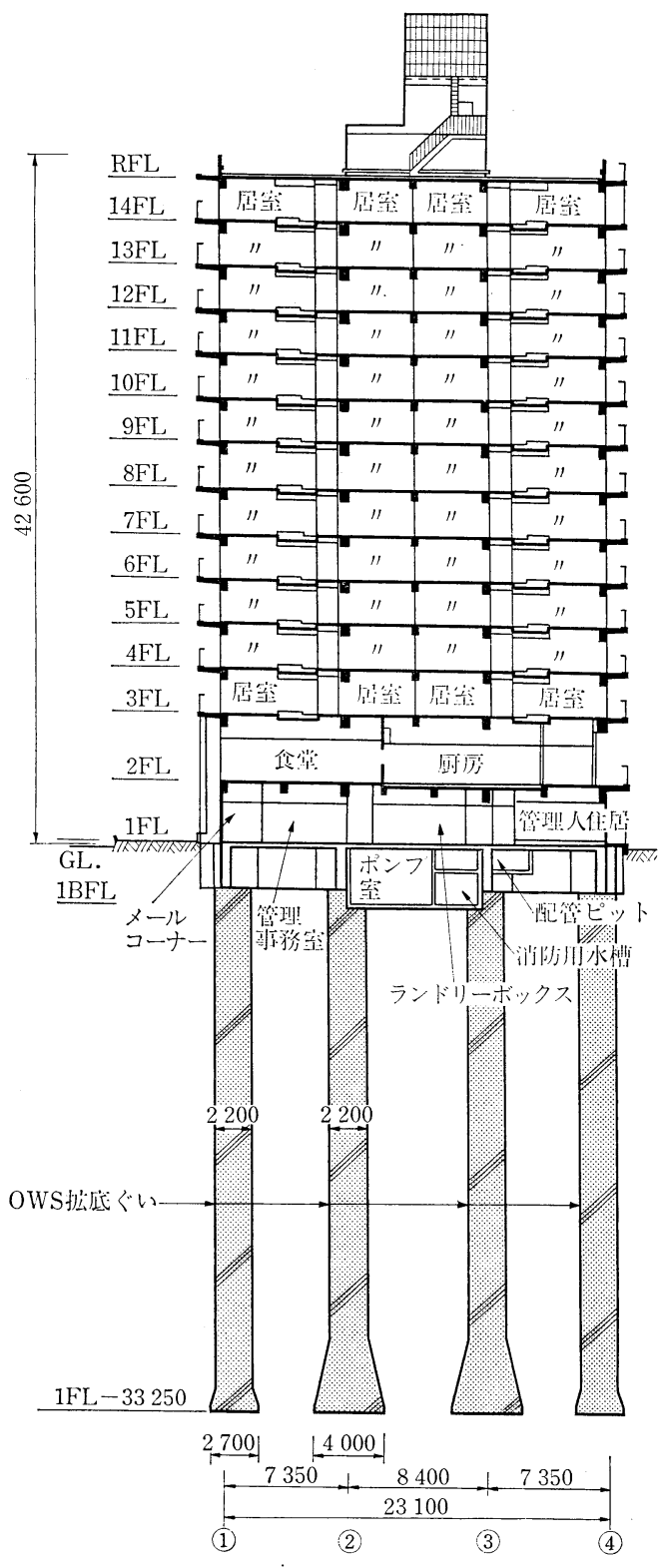

図一4 断面図 (みどり会寮) 
となり，後打ち地中壁との密着状態が良くなるため, 地 下水の豊富な地盤での深い根切り (GL. $-36 \mathrm{~m}$ ) に対し て, 高い止水性を確保することができた。

\section{3. 壁式拡底ぐいの事例}

建物の長辺方向断面を 図一4 亿，土質柱状図を図一5 に示す。この建物は, 長辺が 3 スパン $(23.1 \mathrm{~m})$, 短辺 が 2 スパン $(14.8 \mathrm{~m})$ の寮である。壁式拡底ぐいを支持 ぐいとし, OWS 拡底ぐい工法 (3.2 参照) を採用して いる。地下工事は, 既存ビルの基礎を残した状態で, 新 築工事部分だけをはつり取り，〈い，基礎スラブ，基礎 ばりを施工する SUF 工法 (3.3 参照) を計画している。

\section{1 工事 概 要}

工事名称：みどり会墨田単身寮新築工事

所 在 地: 東京都墨田区緑 4 丁目 19 番地

設計施工 : 侎大林組

全体概要 : SRC 造

地下 1 階, 地上 14 階, 塔屋 2 階 建築面積 $398 \mathrm{~m}^{2}$ 延床面積 $4278 \mathrm{~m}^{2}$

地中壁概要

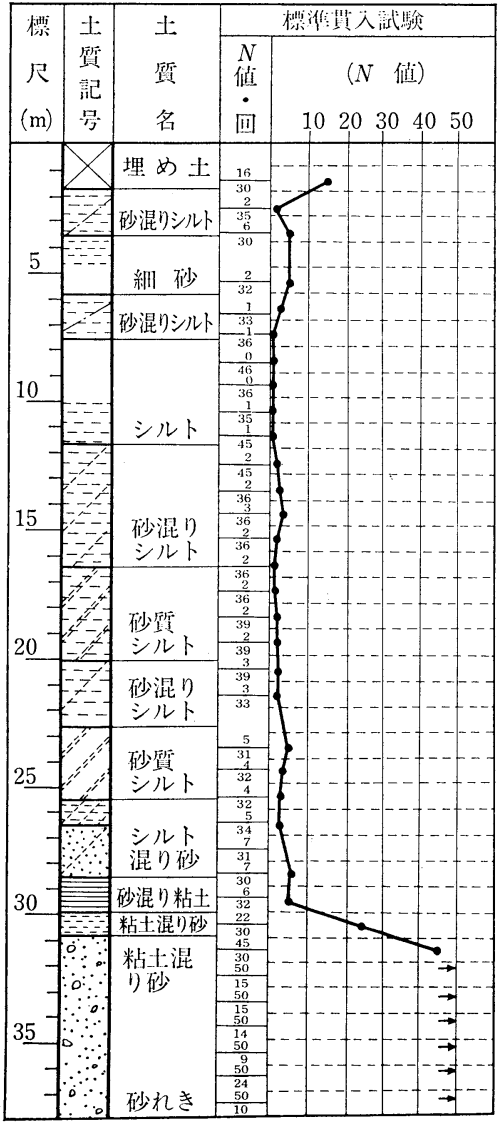

图一5 土質柱状図
用途：支持ぐい(拡底)

壁 厚 : $120 \mathrm{~cm}$

軸 部幅: $220 \mathrm{~cm}$

拡底幅: $270,400 \mathrm{~cm}$

掘削樑さ: GL. $-33 \mathrm{~m}$

くい本数: 12 本

鉄筋量: $92 \mathrm{t}$

コンクリート量 : $1106 \mathrm{~m}^{3}$

工 期 : 27 日

3.2 ows 拡底ぐいエ法によるくいの施工

OWS 拡底ぐい工法とは，OWS-Soletanche 工法によ って構築する地中壁体ぐいの先 端部を,グラブバケット式の Kelly 掘削機 (写真一2) を用い て，壁体面内方向だけを扇形に 拡底掘削し, 支持力の大きな場 所打ち鉄筋コンクリートぐいを 築造する工法である。OWS 拡 底ぐいの概念図を図一6に，施 工寸法を表一2 に示す。

掘削はますす軸部を標準シェ ルで掘削し, 次いで特殊形状の シェル（拡底シェル）を装着し， 図一7に示す要領で切削した。

スライム処理は, 専用の底ざ らいシェルおよび専用のスライ ム処理機を用いて行った。

コンクリートの調合を 表一3 に示す。場所打ちぐいの地中壁

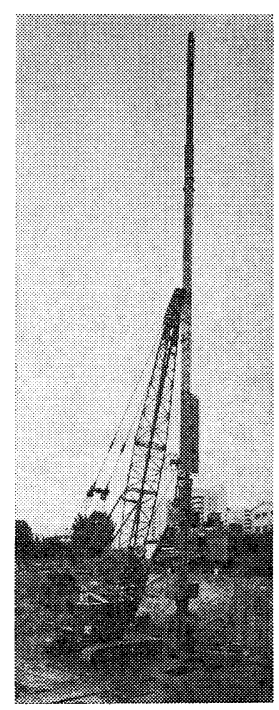

写真—2 Kelly 掘削機 (拡底シェル)

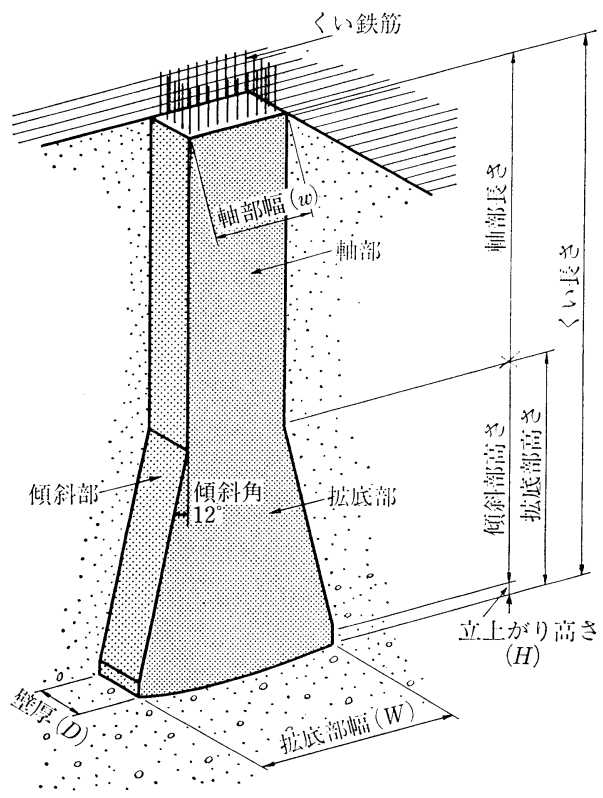

図一6 OWS 拡底ぐい概念図 


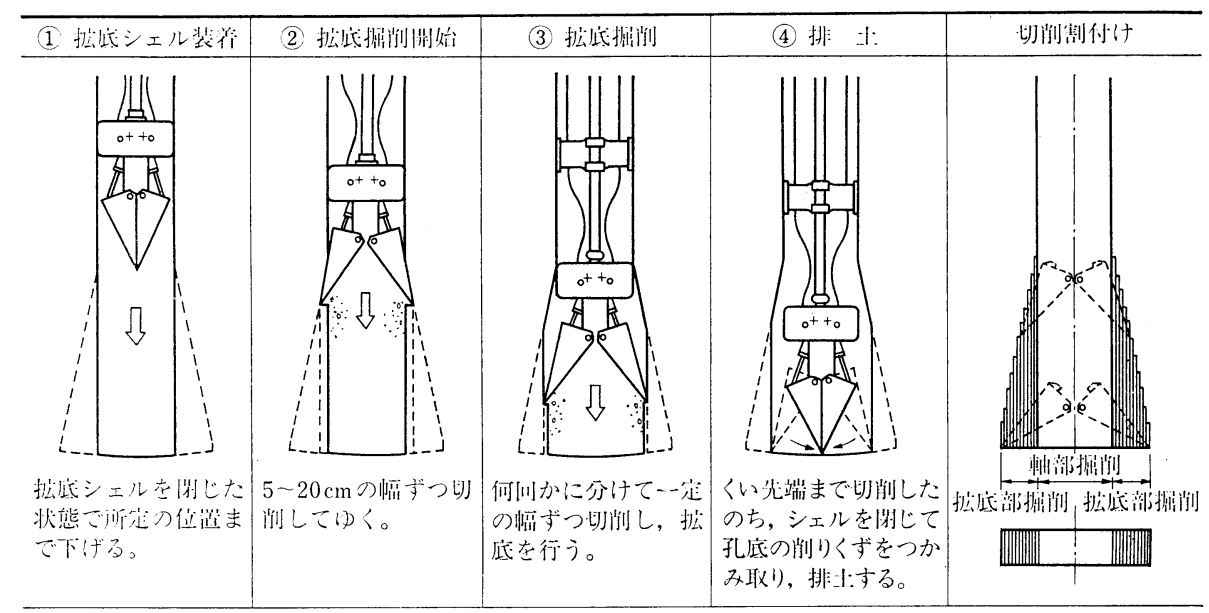

図一7拡 底 掘 削 要 領

表一2 OWS 拡底ぐいの施工寸法

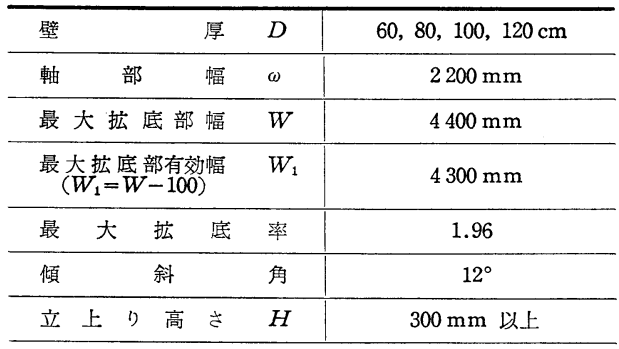

表一3 コンクリートの調合

\begin{tabular}{|c|c|c|c|c|c|c|c|c|}
\hline \multirow{2}{*}{$\begin{array}{l}\text { 設計基隻 } \\
\text { 强 } \\
\left(\mathrm{kg} / \mathrm{cm}^{2}\right)\end{array}$} & \multirow{2}{*}{$\begin{array}{l}\text { スラ } \\
\text { ンテ゚ } \\
(\mathrm{cm})\end{array}$} & \multirow{2}{*}{\begin{tabular}{|l|} 
水七又 \\
$y \vdash$ 比 \\
$W / C$ \\
$(\%)$ \\
$(\%)$
\end{tabular}} & \multirow{2}{*}{$\begin{array}{l}\text { 細骨 } \\
\text { 到率 } \\
\text { s/a } \\
(\%)\end{array}$} & \multicolumn{5}{|c|}{ 単 位 量 $\left(\mathrm{kg} / \mathrm{m}^{3}\right)$} \\
\hline & & & & $C$ & $W$ & $S$ & $G$ & 混和凪 \\
\hline 240 & 20 & 59.0 & 46.9 & 312 & 184 & 827 & 972 & 3.370 \\
\hline
\end{tabular}

であるため, 単位セメント量 $300 \mathrm{~kg}$ 以上, 水セ メント比 $60 \%$ 以下とした以外は, 前述の 2.3 と 同じように定めた。なお，標準養生による材令 28 日の 圧縮強度は $303 \sim 354 \mathrm{kgf} / \mathrm{cm}^{2}$ (平均 334 $\mathrm{kgf} / \mathrm{cm}^{2}$ ) であった。

コンクリートの打設は，拡底端部まで密実なコ ンクリートとなるよう, 拡底幅が $4.0 \mathrm{~m}$ となるくいに ついてはトレミー管 2 本で実施した。

\subsection{SUF エ法による基礎スラブと基礎ばりの施工}

SUF (SG-Unified Foundation) 工法とは, 地下階の ない建物において, OWS-Soletanche 工法によって場 所打ちぐいを施工したのち，根切りを行わないで，同じ 工法によって基礎スラブと基礎ばりを構築して一体化す るものである。SUF 工法の概念図を 図一8 に示すが, その施工手順は次のようである。

1) 作業床の構築 : 既存躯体の一部を解体し, 新築 基礎スラブとはり部分を開口部とした作業床 を構築する。

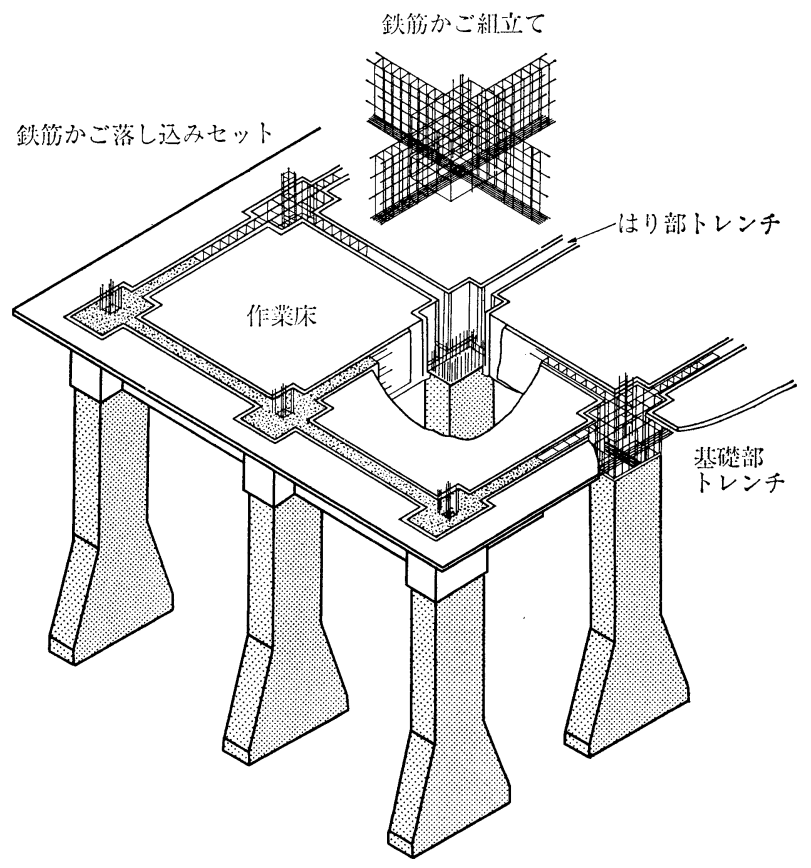

図一8ＳUF 工法概念図

2）基礎部トレンチの構築：自硬性安定液を用い て，基礎部分の型わくとなる山留めトレンチ を構築する。

3）支持ぐいの築造： 基礎部トレンチに囲まれた部 分に壁式拡底ぐいを築造する。

4）はり部トレンチの構築：基礎部トレンチと同じ 手法を用いて，地中ばりのトレンチを構築す る。

5）基礎スラブ・はりの築造： 基礎スラブとはりの 鉄筋を地上で組み立て, ブロックごとに設置 して，順次，コンクリートを打設する。 


\section{4.あとがき}

建築地中壁工事における特色ある施工例として，地下 立体駐車場と壁式抗底ぐいの事例を述べた。

多様で複䧴な現場条件と地質条件のなかで，地中壁に 仮設の山留め壁ばかりでなく, 耐震壁, 土水圧負担壁, さらにくいとしての機能も同時にもたせた，合理的かつ 経済的な計画や，T字ぐい，くし形ぐい，大深度，大断 面などの複雑で高度な品質管理を要求される地中壁が計 画されるようになった。

このことは，地中壁の施工精度の確保，品質管理が現 場において確実に行われ，多くの実績を積むことにより 地中壁の信頼性が大幅に向上したことによるものだと言 えよう。

\footnotetext{
( $《$ 図書案 内》

JCI-C 11

$\mathrm{RC}$ 耐震壁のマクロモデルと FEM ミクロモデル

に関するパネルディスカッション

一研究の現状と問題点一 論文集
}

A 4 判・130 ページ/定価 8000 円 (税 240 円), 会員特価 7000 円 (棁 210 円) ・送料 300 円

本書は，鉄筋コンクリート構造の有限要素解析の設計への応用に関する情報交換を行い，研究および設計の発 展に寄与することを目的として発足した “鉄筋コンクリート構造の有限要素解析と設計法研究委員会” の中間報 告として昭和 63 年 1 月 22 日に行われたパネルディスカッションの論文集である。

[目 次]

1. R C 部材のマクロモデル概説

2. R R C 耐震壁の終局強度に 関する 既往マクロモデルにつ いて

3. R C 耐震部材のせん断設計式の開発

一日本建築学会 RC 耐震設計小委員会せん断 WG の考え方一

4. $\mathrm{RC}$ 耐震壁のマクロモデル間の解析結果の比較および 実験值との比較

5. マクロモデルの適用性に関する研究者の意見・感想

一ミクロモデルは如何に活用できるか一
6. FEM による R C 耐震壁のマクロモデル検証の試み

7. FEM による R C 耐震壁のパラメータ解析

[ 付 $\left.\begin{array}{ll}\text { 録 }\end{array}\right]$ マクロモデルの入出力例とプログラムリスト

付録-1 称原・加藤モデルの入出力例とプログラムリスト

付録-2 南・村上モデルの入出力例とプログラムリスト

付録-3 白石・狩野モデルの入出力例とプログラムリスト

付録-4 塩原モデルの解析例

申申 込 先: (社) 日本コンクリート工学協会「書籍販売係」

干102 千代田区鶄町 5-7 TBR ビル 708 号/電話(03)263-1571

<申込方法〉 書籍名・送付先を明記のうえ，前金 (現金書留)にてお申込みください。 